\title{
Influence of Socio-economic Factors on Empowerment of Farm Women: An in Depth Analysis
}

\author{
J.K. Das ${ }^{1 *}$, S. Bhattacharjee ${ }^{2}$, J. Datta ${ }^{3}$, G. Mazumder ${ }^{4}$ and T. Laskar ${ }^{4}$ \\ ${ }^{1}$ Dept.of Agricultural Extension, Centurion University of Technology and Management, \\ MSSSOA, Paralakhemundi-761211, Gajapati, Odisha, India \\ ${ }^{2}$ The Neotia University, Jhinga, Sarisa, Diamond Harbour, 74332568, WB, India \\ ${ }^{3}$ ATMA, Dept. of Agriculture, Matabari Block, Tripura-799120, India \\ ${ }^{4}$ Department of Agricultural Extension, BCKV, Mohanpur-741252, Nadia, WB, India \\ *Corresponding author
}

\begin{tabular}{|l|}
\hline Keyw or d s \\
Women \\
empowerment, \\
Livelihood and \\
Income
\end{tabular}

\section{Introduction}

The issue of empowerment is very complex as the issues related to women are varied and

\begin{abstract}
A B S T R A C T
Gender Empowerment has been a highly focused area over three decades to empower women so that they can be made free from the mettle of exploitation, deprivation, and social impoverishment. The study was conducted in Haringhata Block under Nadia district of West Bengal. Both purposive as well as simple random sampling was adopted for selection of 100 respondents in five mouzas of the selected block. The present study envisages two components viz. livelihood and income generation as to have conceptual and operational contribution in empowering women adequately and workably. There are 19 independent variables (X1-X19) and 1 independent variable (Empowerment). For the analysis and interpretation statistical tools Correlation of coefficient, Path Analysis, Regression analysis and Canonical Correlation analysis have been used. The results reveal that out of 19 independent variables 14 variable found to have strong significant positive co-relationship at $1 \%$ level of significance (Education $0.529 * *$, Land $0.290^{* *}$, House Type $0.435^{* *}$, Material Possession 0.695**, Family Income 0.406**, Social Participation $0.507^{* *}$, Mass Media Exposure 0.578**, Training 0.432**, Monetary Benefits0.346**, Non monetary Benefits $0.495^{* *}$, Profit utilization Pattern $0.468^{* *}$, Decision making in household activities $0.492 * *$, Decision making in agricultural activities $0.375^{* *}$ and Socio economic activities change after Income Generating Activities $0.744^{* *}$ ) with the predicted variable Empowerment. The variable Socio-Economic status Change shows highest direct effect on Empowerment where as the Family Income shows the highest indirect effect in path analysis. The residual effect is $26 \%$, it could be contributed that the combination of 19 variables had been able to explain $74 \%$ of the variation in the consequent variable i.e. Empowerment. Stepwise Multiple Regression analysis explained $72 \%$ and all predictors in this equation have resulted significant regression coefficient to explain Empowerment.
\end{abstract}

multidimensional. In its simplest form, women empowerment means the manifestation of redistribution of power that challenges patriarchal ideology and the male 
dominance. Empowerment is a multidimensional social process that helps people gain control over their own lives communities, and into heir society, by acting on issues that they define as important. Empowerment occurs within sociological, p[psychological, economic spheres and at various levels, such as individual, group, and community and challenges our assumptions about the status quo, asymmetrical power relationships and social dynamics. Cultural tradition and economic necessity have always meant a significant role for women in agriculture. In India it is not uncommon that women do not control over the land. Even, where women constitute a larger share of agricultural producers but, there are cultural constrains to easy communication between men and women, because almost all extension workers are men. It is very difficult to define empowerment with a universally accepted definition. It has been defined by academics and development agencies like World Bank and NGOs, does not bear the same meaning as used by feminist development theorists and practitioners. However much of the literature views empowerment as a process of change in existing power structure. It is clearly concerned with power, and particularly with the power relations - and the distribution of power-between individuals and groups (Kahlon 2004, Batiwala 1994) defined empowerment as the process of challenging 4existing power relations and of gaining greater control, over the sources of power'. Acharya and Ghirme (2005) identified empowerment as a dynamic and ongoing process that takes place which enhances women's and any other marginalized and alienated groups' abilities to change the structures and ideologies that keep them subordinate. There is no straightforward definition of women empowerment, because the concept of power cannot be streamlined internationally as it differs from societal context (Snijders, 2009). Defining women empowerment process covers many influencing factors, meaning that any definition almost always captures part of the complete process. When defining women empowerment, one of the similarities in the literature is the concept of women's decision making power as an indicator of women empowerment (Snijders, 2009, Malhotra, et al. 2002) stated that defining women empowerment has been done in most studies by using the terms options, choice, control and power. The objectives are: to find out the relationship between the selected consequent and antecedent variable the (Empowerment of Farm Women), to identify the degree to which the Empowerment may be predicted from these characteristics and to understand the different problems faced by the women hindering the empowerment process and measures suggested by them as remedies.

\section{Materials and Methods}

The study was conducted in Haringhata Block under Nadia district of West Bengal. Both purposive as well as simple random sampling was adopted for selection of 100 respondents in five mouzas of the selected block. After pretesting of data collecting device information/data was collected following the personal as well as group interview method. The study was conducted with the Independent variables like Age, Education, Marital Status, Caste, Family Type, Family Type, Family Size, Land Holding, House Type, Material Possession, Family Income, Social Participation, Mass Media Participation, No. of Training undergone, Monetary Benefits, Non Monetary Benefits, Decision Making in House hold Activities, Decision Making in Agricultural Activities, Socio-Economic Status change after joining Income Generating Activities and Dependent variable Empowerment. Analysis of the data has been done using the statistical tools 
Correlation of coefficient, Path Analysis, Regression analysis and Canonical Correlation analysis.

Dependent Variable Empowerment consisted of nine variables Education, Land Ownership, Ownership of other assets (other than land), Control over income contributed by her in the family, Control over the income of the family, Savings, Access to credit, Social participation and Cash income earned from income generating activities.

Based on the score obtained from these nine variables extent of empowerment was calculated by computing the empowerment index (expressed in percentage) as follows:

Score obtained

Empowerment index $=\longdiv { \text { Maximum score obtainable } } \times 1 0 0$

Gain in empowerment was calculated by taking difference between empowerment index value before and after taking income generating activity.

\section{Results and Discussion}

The correlation co-efficient between the independent variables and the empowerment (Y) has been displayed in Table 1.

Out of 19 independent variable age $\left(\mathrm{X}_{1}\right)$, marital status $\left(\mathrm{X}_{3}\right)$, caste $\left(\mathrm{X}_{4}\right)$, family type $\left(\mathrm{X}_{5}\right)$, family size $\left(\mathrm{X}_{6}\right)$ are not found to be significantly related with the Empowerment (Y).

The variables Education $\left(\mathrm{X}_{2}\right)$ ( Bharathamma G. U.2005), Land $\left(X_{7}\right)$ (Bharathamma G. U.2005), House type $\left(\mathrm{X}_{8}\right)$, material possession $\left(\mathrm{X}_{9}\right)$, Family income $\left(\mathrm{X}_{10}\right)$ (Bharathamma G. U.2005), Social participation $\left(\mathrm{X}_{11}\right)$ (Bharathamma G. U.2005), Mass media Exposure $\left(\mathrm{X}_{12}\right)$ Bharathamma G. U.(2005), Number of trainings $\left(\mathrm{X}_{13}\right)$ ( Agarwal 2000), Monetary benefits $\left(X_{14}\right)$, non-monetary benefits $\left(X_{15}\right)$, Profit utilization pattern $\left(\mathrm{X}_{16}\right)$, Decision making in household $\left(\mathrm{X}_{17}\right)$, Decision making in agriculture $\left(\mathrm{X}_{18}\right)$, Socio economic status change $\left(\mathrm{X}_{19}\right)$ are found to be highly correlated with the empowerment (Y).

Table 2, presents the path analysis to explain the direct, indirect and residual effect of antecedent variables on consequent variable i.e. Empowerment.

The result reveals that the variables socio economic status change $\left(\mathrm{X}_{19}\right)$ exerts highest positive direct effects on Gain in Empowerment over the other 18 antecedent variables, which is followed by Mass Media Exposure $\left(\mathrm{X}_{12}\right)$, Material Possession $\left(\mathrm{X}_{9}\right)$, Social Participation $\left(\mathrm{X}_{11}\right)$ and Family Type $\left(\mathrm{X}_{5}\right)$.

It has been found that the variable Age $\left(\mathrm{X}_{1}\right)$ and Family Income $\left(\mathrm{X}_{10}\right)$ exerts highest negative direct effect on Gain in Empowerment over the other 18 antecedent variables, which is followed by $\operatorname{Caste}\left(\mathrm{X}_{4}\right)$, Decision making in agriculture activities $\left(\mathrm{X}_{18}\right)$ and Training No. $\left(\mathrm{X}_{13}\right)$.

The result also reveals that the variable family income $\left(\mathrm{X}_{10}\right)$ exerts highest positive indirect effects on Empowerment over the other 18 antecedent variables followed by Material Possession $\left(\mathrm{X}_{9}\right)$, Education $\left(\mathrm{X}_{2}\right)$, and Training No. $\left(\mathrm{X}_{13}\right)$, Decision making in Household activities $\left(\mathrm{X}_{17}\right)$ respectively. 
It has been found that the variable Age $\left(X_{1}\right)$ exerts highest negative indirect effect on Gain in Empowerment over the other 18 antecedent variables.

The residual effect is $26 \%$, it could be contributed that the combination of 19 variables in this investigation in the form of antecedent variable had been able to explain $74 \%$ of the variation in the consequent variable i.e. Gain in Empowerment.

In table 3 it concluded that Empowerment (Y) is explained by the Socio-Economic status change $\left(\mathrm{X}_{19}\right)$, Mass Media Exposure $\left(\mathrm{X}_{12}\right)$, Material Possession $\left(\mathrm{X}_{9}\right)$ with their positive contribution towards Empowerment (Y) and Age $\left(\mathrm{X}_{1}\right)$ variable with its negative impact towards reducing the magnitude of Y. Total variance explained by such equation is $72 \%$ and all predictors in this equation have resulted significant regression coefficient to explain Empowerment.

Following Canonical Correlation Analysis 5 Canonical associations or dimensions were found significant.

Table 4 represents Standardized Canonical Coefficients for Dependent Variables in 5 Canonical dimensions which were found significant.

Table 5 represents the Standardized Canonical Coefficients for Covariates in 5 Canonical dimensions.

In these 2 tables we considered only those Standardized Canonical Coefficient values which were greater than 0.3 .

$1^{\text {st }}$ Canonical Variate (Table 4) revealed that Material Possession $\left(\mathrm{X}_{9}\right)$, Family Income $\left(\mathrm{X}_{10}\right)$ and Mass media Exposure $\left(\mathrm{X}_{12}\right)$ have positive significant association with Non Monetary Benefits(x15) and Empowerment (Y). $2^{\text {nd }}$ Canonical Variate (Table 5) revealed that Material Possession $\left(\mathrm{X}_{9}\right)$ and Family $\operatorname{Size}\left(\mathrm{X}_{6}\right)$ have positive significant association with Monetary Benefits $\left(\mathrm{X}_{14}\right)$, Decision in Agriculture $\left(\mathrm{X}_{18}\right)$ and Empowerment $(\mathrm{Y})$ and it also revealed that Family Income $\left(\mathrm{X}_{10}\right)$, House Type(X8) and Family Type $\left(\mathrm{X}_{5}\right)$ have positive significant association with Profit Utilization Pattern $\left(\mathrm{X}_{16}\right)$ and Decision making in household related activities $\left(\mathrm{X}_{17}\right)$.

$3^{\text {rd }}$ Canonical Variate (Table 6) revealed that Marital Status $\left(\mathrm{X}_{3}\right)$, Family Income $\left(\mathrm{X}_{10}\right)$ and No. of trainings $\left(\mathrm{X}_{13}\right)$ have positive significant association with Monetary Benefits $\left(\mathrm{X}_{14}\right)$, Non Monetary Benefits $\left(\mathrm{X}_{15}\right)$ and Profit utilization Pattern $\left(\mathrm{X}_{16}\right)$ and it also revealed that $\mathrm{Age}\left(\mathrm{X}_{1}\right)$, Education $\left(\mathrm{X}_{2}\right)$, Land $\left(\mathrm{X}_{7}\right)$, House Type $\left(\mathrm{X}_{8}\right)$ and Social Participation $\left(\mathrm{X}_{11}\right)$ have positive significant association with Socio-economic Status Change $\left(\mathrm{X}_{19}\right)$ and Empowerment $(\mathrm{Y})$.

$4^{\text {th }}$ Canonical Variate (Table 7 ) revealed that Age $\left(\mathrm{X}_{1}\right)$, Family $\operatorname{Size}\left(\mathrm{X}_{6}\right)$, Material Possession $\left(\mathrm{X}_{9}\right)$ and Family Income $\left(\mathrm{X}_{10}\right)$ have positive significant association with Monetary Benefits $\left(\mathrm{X}_{14}\right)$, Non Monetary Benefits $\left(\mathrm{X}_{15}\right)$ and Socio-economic Status change $\left(\mathrm{X}_{19}\right)$ and it also revealed that Marital Status $\left(\mathrm{X}_{3}\right)$, House Type $\left(\mathrm{X}_{8}\right)$ and Social Participation $\left(\mathrm{X}_{11}\right)$ have positive significant association with Profit Utilization Pattern $\left(\mathrm{X}_{16}\right)$, Decision making in Household related activities $\left(\mathrm{X}_{17}\right)$ and Empowerment(Y).

$5^{\text {th }}$ Canonical Variate (Table 8) revealed that Age $\left(X_{1}\right)$, Education $\left(X_{2}\right)$, House Type $\left(X_{8}\right)$ and Social Participation $\left(\mathrm{X}_{11}\right)$ have positive significant association with Profit Utilization Pattern $\left(\mathrm{X}_{16}\right)$, Decision making in Household related activities $\left(\mathrm{X}_{17}\right)$ and Socio-economic Status change $\left(\mathrm{X}_{19}\right)$ and it also revealed that Family Type( $\left.x_{5}\right)$, Land $\left(X_{7}\right)$ and Social Participation $\left(\mathrm{X}_{11}\right)$ have positive significant association with Non Monetary Benefits $\left(\mathrm{X}_{15}\right)$ and Empowerment(Y). 
In this investigation $83.084 \%$ variance of Dependent set and $46.831 \%$ variance of Independent set were explained.26.560\% variance of Dependent set was explained by the Independent set.

Table.1 Correlation coefficient between the Empowerment (Y) and Independent variables $\left(\mathrm{X}_{1^{-}}\right.$ $\left.\mathrm{X}_{19}\right)$

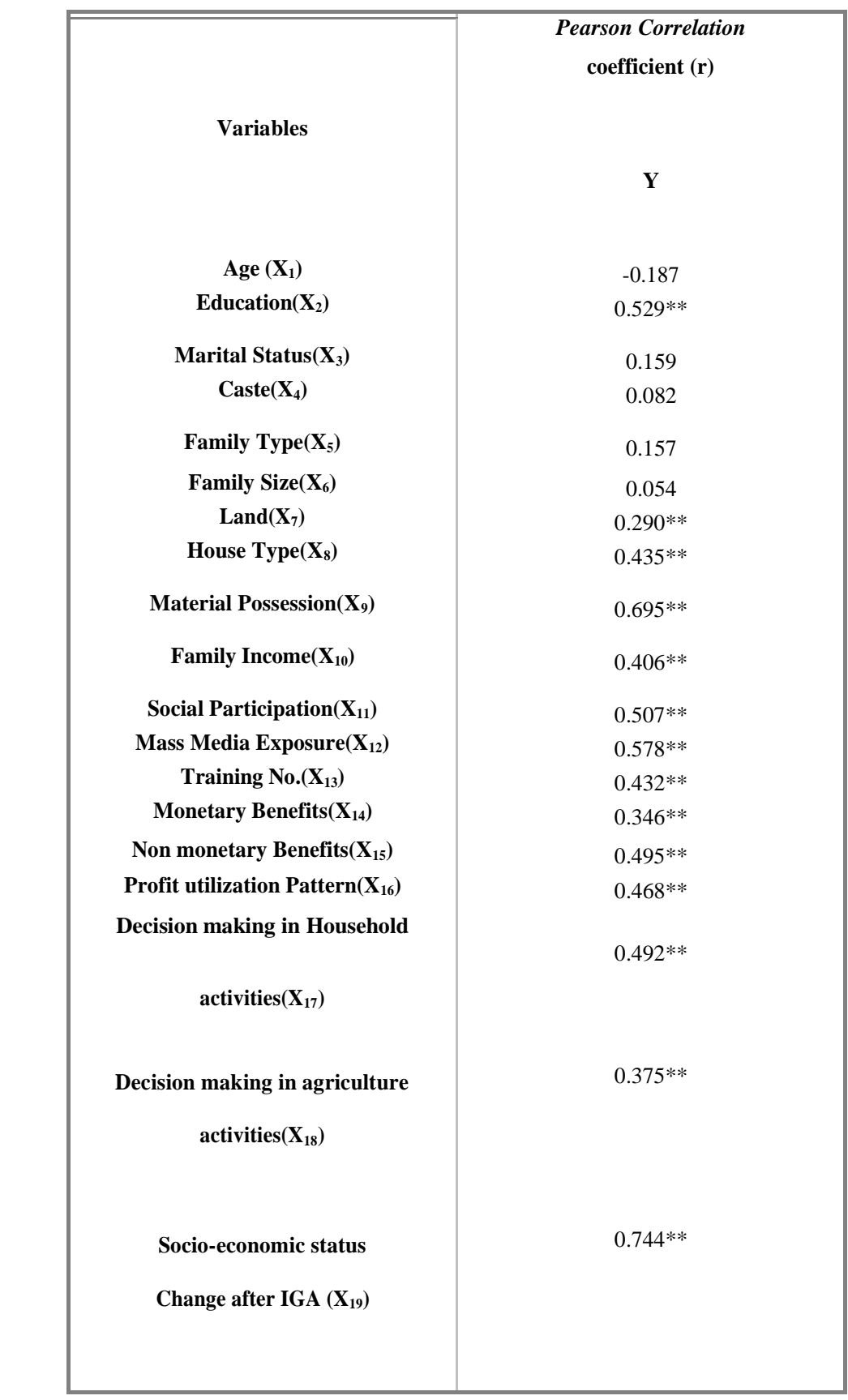

**Significant at $1 \%$ level of significance $(0.256)$ 
Table.2 Path Analysis for deriving Direct, Indirect and Residual effect of antecedent variable on consequent variable Y (Empowerment) Vs the 19 antecedent variables $\left(\mathrm{X}_{1}-\mathrm{X}_{19}\right)$

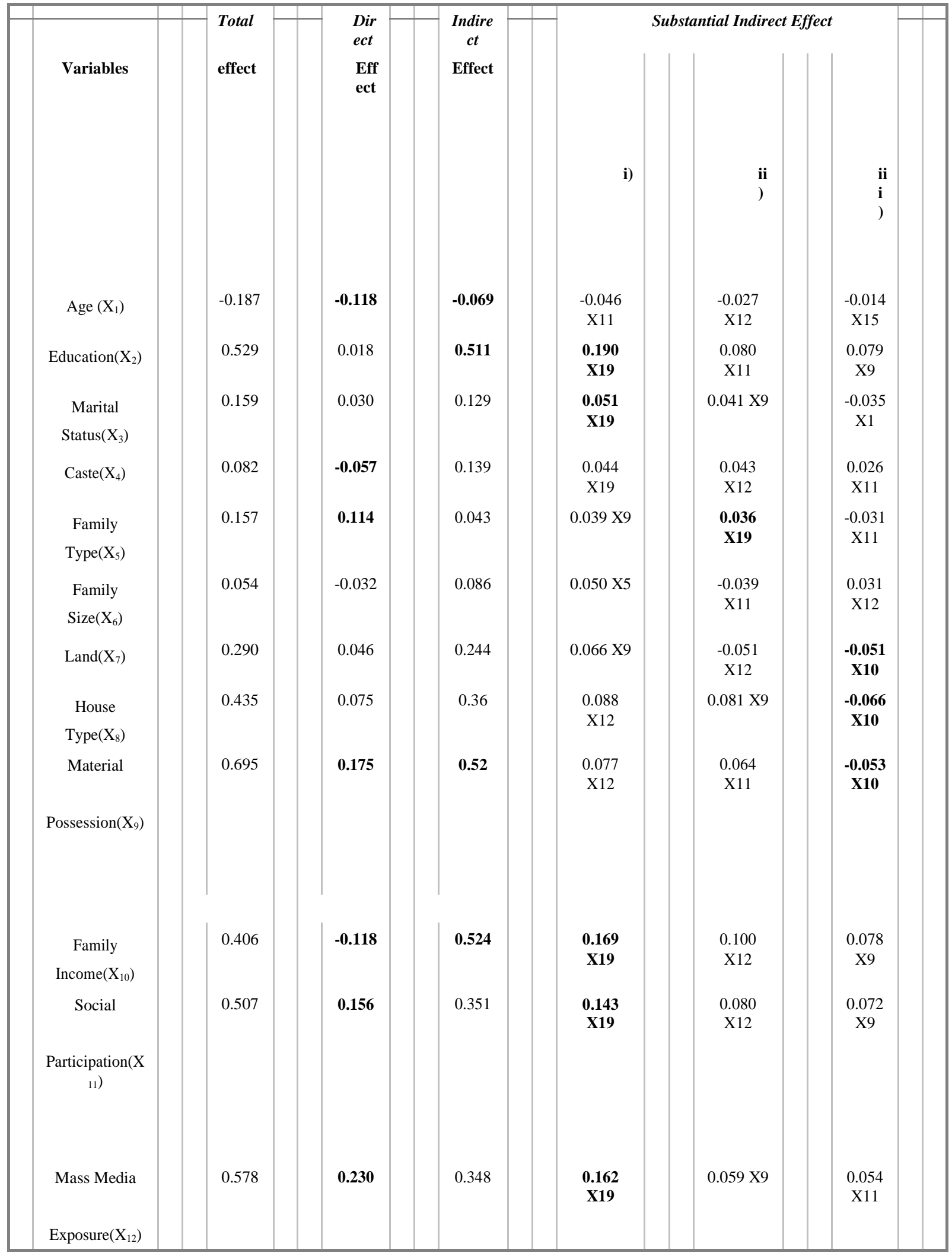




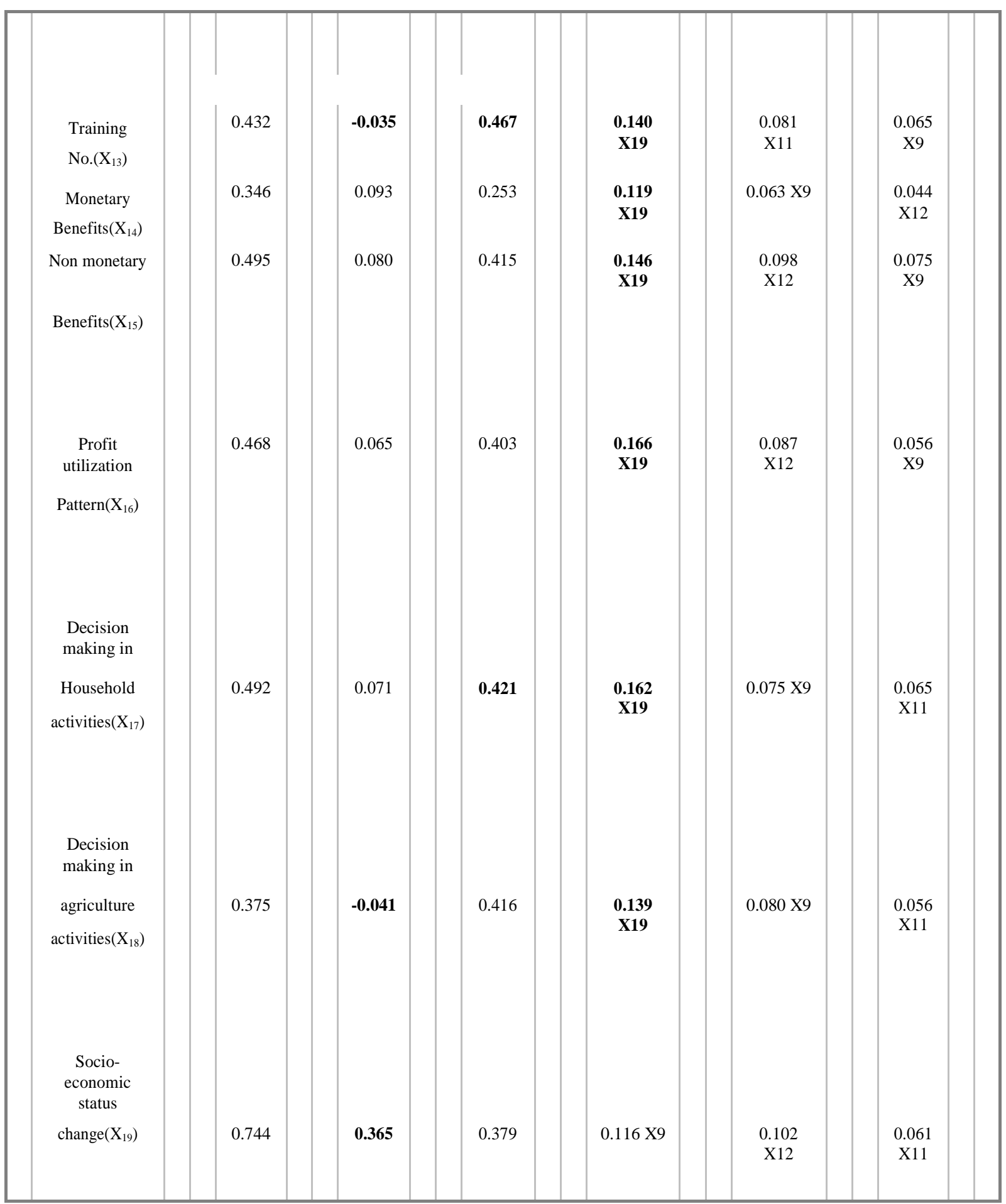

Residual Effect $=0.26$ 
Table.3 Stepwise Multiple Regression analysis between the Empowerment and independent variables $\left(\mathrm{X}_{1}-\mathrm{X}_{19}\right)$

\begin{tabular}{|c|c|c|c|c|c|}
\hline & \multicolumn{2}{|c|}{ Unstandardized } & Standardized & & \\
\hline Variable & \multicolumn{2}{|c|}{ Coefficients } & Coefficients & $\mathbf{t}$ & Sig. \\
\hline & B & Std. Error & Beta & & \\
\hline (Constant) & -1.03 & 2.27 & & - & 0.65 \\
\hline Socio & & & & & \\
\hline Economic & 1.87 & 0.35 & 0.41 & 5.29 & 0.00 \\
\hline Mass Media & 1.84 & 0.43 & 0.27 & 4.33 & 0.00 \\
\hline \multicolumn{6}{|l|}{ Exposure } \\
\hline Material & 0.86 & 0.19 & 0.33 & 4.47 & 0.00 \\
\hline \multicolumn{6}{|l|}{ Possession } \\
\hline Age & -0.12 & 0.04 & -0.15 & - & 0.01 \\
\hline & \multicolumn{3}{|c|}{ Dependent Variable: Empowerment } & & \\
\hline $\mathrm{R}$ & R Sq. & Adj.R Sq. & $\mathrm{SE}$ (est.) & & \\
\hline 0.85 & 0.72 & 0.70 & 4.32 & & \\
\hline
\end{tabular}

Table.4 Eigen values and canonical correlation analysis

\begin{tabular}{|c|c|c|c|c|c|}
\hline Root No. & Eigenvalue & Pct. & Cum. Pct. & Canon Cor. & Sq. Cor. \\
\hline $\mathbf{1}$ & 3.290 & 50.845 & 50.845 & .876 & .767 \\
\hline $\mathbf{2}$ & 1.362 & 21.045 & 71.890 & .759 & .577 \\
\hline $\mathbf{3}$ & .822 & 12.710 & 84.600 & .672 & .451 \\
\hline $\mathbf{4}$ & .437 & 6.748 & 91.348 & .551 & .304 \\
\hline $\mathbf{5}$ & .260 & 4.023 & 95.371 & .454 & .207 \\
\hline $\mathbf{6}$ & .183 & 2.831 & 98.202 & .393 & .155 \\
\hline $\mathbf{7}$ & .116 & 1.798 & 100.000 & .323 & .104 \\
\hline
\end{tabular}


Table.5 Dimension reduction analysis

\begin{tabular}{|c|c|c|c|c|c|}
\hline Roots & Wilks L. & F Hypoth. & DF & Error DF & Sig of F \\
\hline 1 to 7 & .02264 & 4.66015 & 91.00 & 507.18 & .000 \\
\hline 2 to 7 & .09714 & 3.31800 & 72.00 & 446.49 & .000 \\
\hline 3 to 7 & .22942 & 2.60853 & 55.00 & 383.15 & .000 \\
\hline $\mathbf{4}$ to 7 & .41812 & 2.04632 & 40.00 & 316.58 & .000 \\
\hline $\mathbf{5}$ to 7 & .60070 & 1.73690 & 27.00 & 245.97 & .016 \\
\hline 6 to7 & .75707 & 1.58626 & 16.00 & 170.00 & .077 \\
\hline 7 to 7 & .89575 & 1.42979 & 7.00 & 86.00 & .204 \\
\hline
\end{tabular}

Table.6 Standardized canonical coefficients for dependent variables function no

\begin{tabular}{|c|c|c|c|c|c|}
\hline Variable & $\mathbf{1}$ & $\mathbf{2}$ & $\mathbf{3}$ & $\mathbf{4}$ & $\mathbf{5}$ \\
\hline Monetary Benefit & -.116 & -.315 & -.735 & -.521 & -.039 \\
\hline Non Monetary & -.366 & .228 & -.364 & -.429 & .552 \\
\hline Benefit & & & & & \\
\hline Profit Utilization & -.123 & .402 & -.385 & .336 & -.383 \\
\hline Pattern & & & & & \\
\hline Decision making & & & & & \\
\hline in Household & -.110 & .499 & -.154 & .773 & -.527 \\
\hline $\begin{array}{c}\text { Activities } \\
\text { Decision making }\end{array}$ & & & & & \\
\hline in Agricultural & .102 & -1.247 & -.151 & -.156 & .129 \\
\hline Activities & & & & -.817 & -1.003 \\
\hline Socio-Economic & -.248 & .183 & .698 & & \\
\hline status change & & & & & \\
\hline & -.413 & -.302 & .469 & .675 & \\
\hline Empowerment & & & & & \\
\hline
\end{tabular}

Table.7 Variance in dependent variables explained by canonical variables

\begin{tabular}{|c|c|c|c|c|}
\hline CAN. VAR. & Pct Var DE & Cum Pct DE & Pct Var CO & Cum Pct CO \\
\hline $\mathbf{1}$ & 43.905 & 43.905 & 33.671 & 33.671 \\
\hline $\mathbf{2}$ & 9.920 & 53.825 & 5.720 & 39.391 \\
\hline $\mathbf{3}$ & 9.488 & 63.313 & 4.282 & 43.673 \\
\hline $\mathbf{4}$ & 10.982 & 74.295 & 3.338 & 47.011 \\
\hline $\mathbf{5}$ & 8.789 & 83.084 & 1.815 & 48.826 \\
\hline
\end{tabular}


Table.8 Standardized canonical coefficients for covariates can var

\begin{tabular}{|c|c|c|c|c|c|}
\hline COVARIATE & $\mathbf{1}$ & $\mathbf{2}$ & $\mathbf{3}$ & $\mathbf{4}$ & $\mathbf{5}$ \\
\hline Age & .101 & .077 & .561 & -.392 & -.863 \\
\hline Education & -.145 & .217 & .610 & -.272 & -.697 \\
\hline Marital Status & -.241 & .158 & -.579 & .311 & -.125 \\
\hline Caste & -.052 & .033 & .029 & .012 & -.085 \\
\hline Family Type & -.168 & .303 & -.141 & .248 & .373 \\
\hline Family Size & .041 & -.384 & -.024 & -.595 & .094 \\
\hline Land & .073 & -.124 & .397 & -.113 & .398 \\
\hline House & .097 & .370 & .403 & .792 & -.302 \\
\hline
\end{tabular}

Table.9 Constraints in empowerment as perceived by farm women

\begin{tabular}{|c|c|c|c|c|}
\hline Serial & Constraints & Frequency & Percentage & Ranks \\
\hline No. & & & & \\
\hline 1. & Lack of acquisition & 90 & 90 & I \\
\hline 2. & $\begin{array}{l}\text { Over burdened with dual } \\
\text { responsibility of managing }\end{array}$ & 87 & 87 & II \\
\hline & $\begin{array}{c}\text { household and economic } \\
\text { activities }\end{array}$ & & & \\
\hline 3. & Lack of proper training & $80^{\prime}$ & 80 & III \\
\hline & Lack of finance to take up any & & & \\
\hline 4. & activity & 75 & 75 & IV \\
\hline 5. & Income derived is too little & 70 & 70 & $\mathrm{~V}$ \\
\hline 6. & Family restriction for mobility & $40^{\prime}$ & 40 & VI \\
\hline 7. & $\begin{array}{c}\text { Lack of freedom to take } \\
\text { decision }\end{array}$ & $35^{\prime}$ & 35 & VII \\
\hline 8. & Loans are not sufficient & 25 & 25 & VIII \\
\hline
\end{tabular}

In table 9 it has been found that the major problem faced by the farm women is Lack of acquisition (90\%), it got the rank I, followed by dual responsibility (87\%) ranked II (Saini et al., 2010). Lack of proper training $(80 \%)$ ranked III, another important impediment for empowerment listed IV was lack of finance for taking up any activity (75\%). Other problems ranked chronologically according to their severity that are Income derived is too 
little $(70 \%)$ ranked V, Family for mobility (40\%) ranked VI, Lack of freedom to take decision (35\%) listed VII and lastly Loans are not sufficient $(25 \%)$ for survival of the enterprise and so got the last rank VIII.

\section{Suggestion of the farm women}

There should be an arrangement of evening classes for every woman in the villages

Training programmes should be organized frequently by district rural development agencies, commercial banks and NGOs.

Bank officials should be cooperative to give them loans whenever necessary.

Family members should be understanding with them and give them enough freedom for mobility.

Adult members of the family should help them in managing both household and economic activities.

All the decisions should be made by male members after consultation with the female members of the family.

Government should take necessary steps so that their income should be high.

\section{References}

Acharya and Ghrime, (2005):'Gender indicators of equality, inclusion and Poverty reduction: Measuring programmes and project effectiveness', Economic and Political weekly 40 (44-45), March 20 2009 issue.

Agarwal, D. (2000). 'Capacity building for rural women'. Social Welfare, 47(4): 7-9.
Bharathamma G. U. (2005). 'Empowerment of rural women through income generating activities in gadag district of North Karnataka'. M. Sc. (Agri.) Thesis, University of Agriculture Sciences, Dharwad - 58000

Batiwala, Srilatha, (1994): 'The meanings of women's empowerment: New Concepts from action in G. Sen, A. Germin and L.C. Chen (eds), Population Policies Reconsidered : Health, Employment and Rights, Harvard University Press.

Kahlon, P., (2004). ' $73^{\text {rd }}$ amendment and women's empowerment: A Punjab study' A paper presented in the seminar on Rural Women and Economic Empowerment of Women in South Asia at GB Pant Social Science Institute, Allahabad.

Malhotra, A., Schuler, S.R. and Boender, C., (2002). 'Measuring Women's Empowerment as a Variable in International Development'. Background Paper Prepared for the World Bank Workshop on Poverty and Gender: New Perspectives. Final Version

Saini,-S-K; Prabhjot-Kaur; Shabana-Yasmin (2010). Empowerment of women for rural livelihood. Agriculture Update, Aug-Nov., Vol.5, Issue 3\&4. 520525.

Snijders, Anna-Larisa, (2009). 'Women Empowerment in South India, A study on the impacts of microfinance through Self Help Groups', Erasmus University Rotterdam

\section{How to cite this article:}

Das, J.K., S. Bhattacharjee, J. Datta, G. Mazumder and Laskar, T. 2019. Influence of Socioeconomic Factors on Empowerment of Farm Women: An in Depth Analysis. Int.J.Curr.Microbiol.App.Sci. 8(07): 967-977. doi: https://doi.org/10.20546/ijcmas.2019.807.116 